\title{
First record of Conostigmus Dahlbom, 1858 (Hymenoptera: Megaspilidae) from Brazil and description of the female of Conostigmus binasutus Dessart \& Cancemi, 1986
}

\author{
C. Pezzini ${ }^{a, b *}$ (I) and A. Köhler ${ }^{b}$ \\ ${ }^{\text {a}}$ Laboratório de Controle Biológico, Departamento de Fitossanidade, Universidade Federal do Rio Grande do Sul - \\ UFRGS, Avenida Bento Gonçalves, 7712, CEP 91540-000, Porto Alegre, RS, Brasil \\ bLaboratório de Entomologia, Departamento de Biologia e Farmácia, Universidade de Santa Cruz do Sul - UNISC, \\ Avenida Independência, 2293, CEP 96815-900, Santa Cruz do Sul, RS, Brasil \\ *cleder.pezzini@hotmail.com
}

Received: August 6, 2018 - Accepted: February 20, 2019 - Distributed: May 31, 2020

(With 2 figures)

\begin{abstract}
Conostigmus Dahlbom, 1858 (Hymenoptera: Megaspilidae) is reported for the first time from Brazil. Here, we provide a diagnosis of Conostigmus binasutus Dessart \& Cancemi, 1986 and the description and illustration of the female, previously unknown. The analyzed material was collected utilizing Malaise traps, in Manaus, Amazon, Brazil and deposited at the Invertebrate collection of INPA (Instituto Nacional de Pesquisas da Amazônia) of Manaus. A identification key and distribution map to the Neotropical species of Conostigmus is provided.
\end{abstract}

Keywords: Ceraphronoidea, taxonomy, biodiversity, Amazon.

\section{Primeiro registro de Conostigmus Dahlbom, 1858 (Hymenoptera: Megaspilidae) para o Brasil e descrição da fêmea de Conostigmus binasutus Dessart \& Cancemi, 1986}

\begin{abstract}
Resumo
Conostigmus Dahlbom, 1858 (Hymenoptera: Megaspilidae) é relatado pela primeira vez no Brasil. Aqui, nós fornecemos a diagnose de Conostigmus binasutus Dessart \& Cancemi, 1986 e descrição e ilustração da fêmea, desconhecida anteriormente. O material analisado foi coletado utilizando armadilha Malaise, em Manaus, Amazonas, Brasil, e está depositado na Coleção de invertebrados do INPA (Instituto Nacional de Pesquisas da Amazônia) de Manaus. Além disso, é apresentada uma chave de identificação e mapa de distribuição das espécies Neotropicais de Conostigmus.
\end{abstract}

Palavras-chave: Ceraphronoidea, taxonomia, biodiversidade, Amazônia.

\section{Introduction}

Megaspilidae Ashmead, 1893 is easily recognized and separated from other families of Hymenoptera for presenting fore wing usually with large stigma and mesoscutum commonly with three longitudinal furrows or rarely reduced to a narrow sclerite (Goulet and Huber, 1993). Little data are available about the biology of Megaspilidae. Are generally ectoparasitoids which attacking, primarily on Diptera, Neuroptera, Coleoptera, Mecoptera and also as hyperparasitoids of Hymenoptera (Dessart, 2006).

Megaspilidae is a cosmopolitan family, includes 308 valid species in 12 genera (HOL, 2018), classified in two subfamilies, Lagynodinae Masner \& Dessart, 1967 and Megaspilinae Ashmead, 1893 (Dessart, 2006). The South American fauna is little known. The largest subfamily is Megaspilinae, and for Brazilian fauna, there are two genera known: Dendrocerus Ratzeburg, 1852 recorded with five species, in many regions of Brazil; and Trichosteresis Förster, 1856 with one species, in São Paulo state (Dessart and Cancemi, 1986; Dessart, 1987; Dessart, 1996; Tavares, 1996; Macedo and Kawada, 2013; Pezzini et al., 2014; Iemma et al., 2016; Pezzini and Köhler, 2017; Margaría, 2018).

Conostigmus Dahlbom, 1858 differs of other genres of Megaspilidae by the following characteristics: ocelli forming an isosceles triangle with a narrow base, or an equilateral triangle (Dessart, 2006). Conostigmus is the second richest genus of Megaspilidae, comprises 163 species and has a worldwide distribution (Johnson and Musetti, 2004). It is more diverse in the Palearctic region (Mikó et al., 2016). For the Neotropical region there are two species known: Conostigmus binasutus Dessart \& Cancemi, 1986 from Ecuador, and Conostigmus yunquensis Ogloblin, 1957 from Chile (Dessart and Cancemi, 1986; Dessart, 1995). The main objective of this work is to record the 
first occurrence of Conostigmus from Brazil and provide the diagnosis, description and illustration of the female of $C$. binasutus previously unknown.

\section{Material and Methods}

Specimens of Conostigmus was collected with malaise trap in a PDBFF (Projeto Dinâmica Biológica de Fragmentos Florestais) reserve (2॰25'12’'S 59॰50'52'W). Specimens was deposited at Invertebrate collection of INPA (Instituto Nacional de Pesquisas da Amazônia) in Manaus, Amazon, Brazil. Specimens was identified with a Motic Quimis Q764ZT stereomicroscope. Morphological terminology follows Dessart and Cancemi (1986), Dessart (1997) and the sculpturing integument Harris (1979).

Photographs were taken using a Nikon AZ100M stereomicroscope and NIS-Elements Advanced Research software and enhanced using Adobe Photoshop CS5 software. A map with the distribution of Neotropical Conostigmus species was constructed. Coordinates of localities were obtained from specimen labels, using Google Earth $^{\circledast}$ application. The distribution map was constructed in Simple Mappr (Shorthouse, 2010).

\section{Results}

\subsection{Diagnosis of C. binasutus}

Head black, narrower than the mesosoma, with sparse pubescence. Two prominences (frons and clypeus). Eyes with few long setae scattered on surface, orbits deep and faveolate. Ocelli forming an almost equilateral triangle. Preoccipital lunula very strong, concave. Preoccipital groove widely faveolate (Figure 1A and F). Antenna dark brown, with fairly thin scape (Figure 1A-C). Mesosoma black, slightly elongated. Mesoscutum transverse, reduced and narrow. Median groove and especially notauli deeply faveolate. Scutellum elongated and limited by a strongly faveolate edge. Scutellum with prominent concave spur at posterior edge (Figure 1B and D). Dark legs, only anterior and middle tibia and tarsus, posterior trochanter and tarsus light brown. Legs slender and basal tarsomeres very long (Figure 1B). Fore wings slightly brownish, stigma more than $2 \mathrm{x}$ as long as wide, poststigmal vein $1.5 \mathrm{x}$ as long as stigma. (Figure 1B and G). Metasoma dark brown. Gaster long and narrow, tergite I with well-defined grooves at basal portion (Figure 1A, B, E).
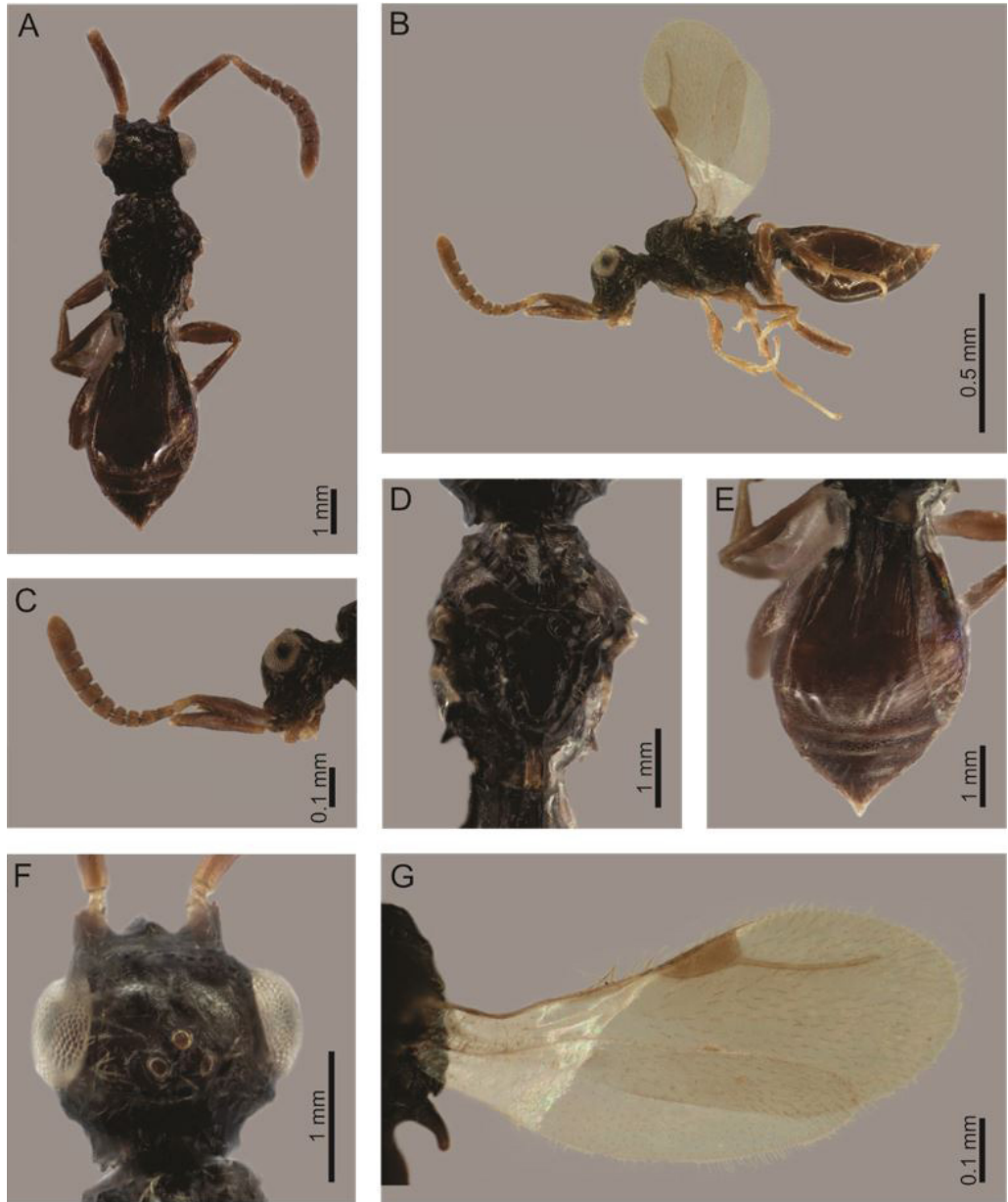

Figure 1. Female of Conostigmus binasutus: A) Dorsal view; B) Lateral view; C) Head (lateral view); D) Mesosoma (dorsal view); E) Metasoma (dorsal view); F) Head (dorsal view); G) Fore and hind wings. 


\subsection{Male}

Holotype with incomplete antenna. Antennae with scape $5 \mathrm{x}$ as long as wide. Pedicel light brown. First flagellomere more than $4 \mathrm{x}$ as long as wide. First flagellomere more than $4 \mathrm{x}$ as long as wide. Other flagellomeres $2 \mathrm{x}$ as long as wide (Dessart and Cancemi, 1986).

\subsection{Description of the female}

Body color and the morphological features of head, mesosoma, wings and metasoma are the same as male, except the antennal segments. Specimen with one damaged antenna.

Antennae with scape more than $4 \mathrm{x}$ as long as wide. Pedicel light brown. Pedicel and first flagellomere: $2 \mathrm{x}$ as long as wide. Second to eighth flagellomere: $2 \mathrm{x}$ as wide as long. Flagellomere 9 the same length of flagellomeres 7 and 8 together. Setae shorter than width of flagellomeres (Figure 1A-C).

Material examined: BRAZIL. Amazonas: Manaus, Malaise trap, Klein Bert Leg. n 1112, 1 ㅇ, 02.vii.1986.

Distribution: Brazil and Ecuador.

Biology: Unknown.

\section{Comments}

The specie Conostigmus uninasutus Alekseev, 1994, collected in Vietnam is the most similar to C. binasutus. The characteristics that distinguish the two species are: C. uninasutus (head with only one prominence in the frons; grooves gastral reaching 33\% length gastral tergite III; yellow legs) and C. binasutus (head with two prominences in the frons and clypeus; grooves gastral surpassing 50\% length gastral tergite III; brown legs).

Identification key and distribution map (Figure 2) to the Neotropical species of Conostigmus is presented (Adapted from Pezzini and Köhler, 2017).

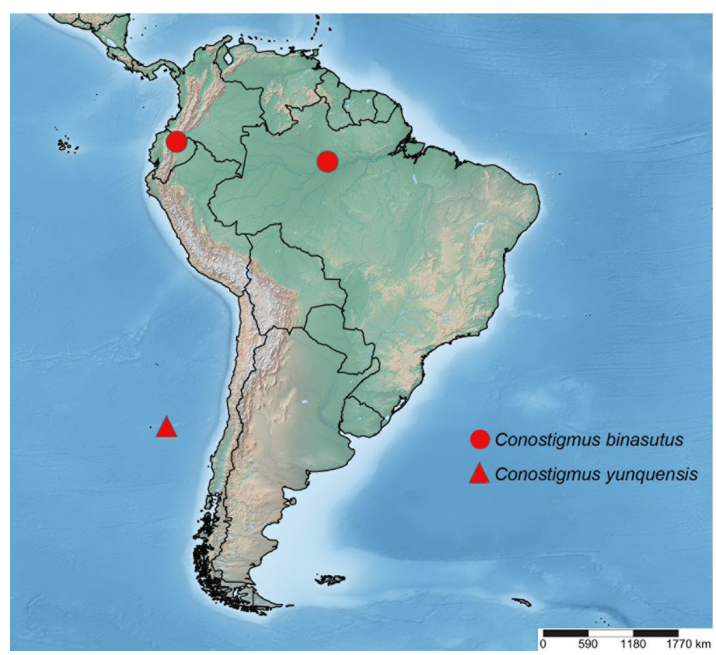

Figure 2. Distribution of Conostigmus species of the Neotropical Region.
1.1 Notaulices angulated anteriorly and converging posteriorly, deeply foveolate; scutellum with a prominent concave spur posteriorly C. binasutus

1.2 Notaulices angulated anteriorly and slightly convergent posteriorly, not favoleate; scutellum without a prominent concave spur posteriorly C. yunquensis

\section{Acknowledgements}

We are grateful to the INPA - Instituto Nacional de Pesquisas da Amazônia, by the loan of the specimen. In addition, we are thankful to Stéphanie Davister, Library of Agricultural Sciences, Université de Liège, Belgium, for sending copies of the taxonomic works of the late Paul Dessart; to José Ricardo Assmann Lemes who helped us with photographs. We also thank Conselho Nacional de Desenvolvimento Científico e Tecnológico (CNPq) for financial support.

\section{References}

DESSART, P. and CANCEMI, P., 1986. Tableau dichotomique dês genres de Ceraphronidae (Hymenoptera) avec commentaries et nouvelles especes. Frustula Entomologica, vol. 7-8, pp. 307-372.

DESSART, P., 1987. Dendrocerus phallocrates sp. n. d'Amérique du Sud (Hymenoptera Ceraphronoidea Megaspilidae). Bulletin et Annales de la Société Royale Belge de Entomologie, vol. 123, pp. 137-140.

DESSART, P., 1995. Revision de deux Ceraphronoidea décrits par A. A. OGLOBIN (Hymenoptera). Bulletin et Annales de la Société Royale Belge de Entomologie, vol. 131, pp. 295-303.

DESSART, P., 1996. Notules hyménoptérologiques nos. 10-21 (Ceraphronoidea; Chalcidoidea Pteromaliadae). Bulletin et Annales de la Société Royale Belge de Entomologie, vol. 132, pp. 277-299.

DESSART, P., 1997. Les Megaspilinae ni européens, ni américains 1. Le genre Conostigmus Dahlbom, 1858 (Hym. Ceraphronoidea Megaspilidae). Mémoires de la Societé royale belge d'Entomologie, vol. 37, pp. 1-144.

DESSART, P., 2006. Family Megaspilidae. In: P.E. HANSON and I.D. GOULD, eds. Hymenoptera de la Región Neotropical. Gainesville: Memoirs of the American Entomological Institute, pp. 232-236.

GOULET, H. and HUBER, J.T., 1993. Hymenoptera of the World: an identification guide to families. Ottawa: Agriculture Canada, $668 \mathrm{p}$.

HARRIS, R.A., 1979. A glossary of surface sculpturing. Occasional Papers in Entomology, vol. 28, pp. 1-31.

Hymenoptera Online-HOL. 2018 [viewed 19 December 2018]. Hymenoptera Online. Available from: https://hol.osu.edu/index. $\mathrm{html}$ ?id=91

IEMMA, L.G.R., TAVARES, M.T. and SOUSA-SILVA, C.R., 2016. First record of Dendrocerus carpenteri (Hymenoptera: Megaspilidae) on Aphidius ervi in alfalfa fields in Brazil. Brazilian Journal of Biology = Revista Brasileira de Biologia, vol. 76, no. 4, pp. 1066-1067. http://dx.doi.org/10.1590/1519-6984.07215. PMid:27191465.

JOHNSON, N.F. and MUSETTI, L., 2004. Catalog of the systematic literature of the superfamily Ceraphronoidea (Hymenoptera). 
Contributions of the American Entomological Institute, vol. 33, no. 2, pp. 1-149.

MACEDO, A.C.C. and KAWADA, R., 2013. First record of Trichosteresis Förster (Hymenoptera: Megaspilidae) from South America. Zootaxa, vol. 3599, no. 3, pp. 298-300. http://dx.doi. org/10.11646/zootaxa.3599.3.7. PMid:24613877.

MARGARÍA, C., 2018 [viewed 13 July 2018]. Megaspilidae Ashmead, 1893. In: Catálogo taxonômico da fauna do Brasil [online]. Brasília: CTFB. Available from: http://fauna.jbrj.gov. $\mathrm{br} /$ fauna/faunadobrasil//701

MIKÓ, I., TRIETSCH, C., SANDALL, E.L., YODER, M.J., HINES, H. and DEANS, A.R., 2016. Malagasy Conostigmus (Hymenoptera: Ceraphronoidea) and the secret of scutes. PeerJ, vol. 4 , no. 4 , pp. 1-87. http://dx.doi.org/10.7717/peerj.2682. PMid:27994960.
PEZZINI, C. and KÖHLER, A., 2017. Annotated keys to the species of Megaspilidae (Hymenoptera: Ceraphronoidea) of the Neotropical Region. EntomoBrasilis, vol. 10, no. 1, pp. 37-43. http://dx.doi.org/10.12741/ebrasilis.v10i1.660.

PEZZINI, C., ZILCH, K.C.F. and KÖHLER, A., 2014. A new species of Dendrocerus (Hymenoptera, Megaspilidae) from southern Brazil. ZooKeys, vol. 425, no. 425, pp. 51-57. http:// dx.doi.org/10.3897/zookeys.425.7454. PMid:25147448.

SHORTHOUSE, D.P., 2010 [viewed 18 December 2018]. SimpleMappr, an online tool to produce publication-quality point maps [online]. SimpleMappr. Available from: http://www. simplemappr.net

TAVARES, M.T., 1996. Ocorrência de Dendrocerus carpenteri (Curtis) (Hymenoptera: Megaspilidae) no Brasil. Anais da Sociedade Entomológica do Brasil, vol. 25, no. 2, pp. 363-364. 